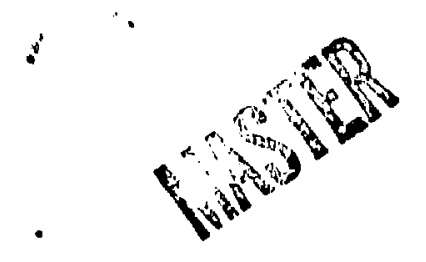

\title{
CORROSION OF STEEL TENDONS USED IN PRESTRESSED CONCRETE PRESSURE VESSELS*
}

J. C. Griess and D. J. Naus Oak Ridge National Laboratory Oak Ridge, Tennessee 37830

By ceceptence of this arriele, the publiaher or reclpient ceknowledges the U.S. Government's right to rotain e nonexclusive, royelty-tree license in end so any copyright covering the areicis.
$\operatorname{CoN}-781232--1$
Tha report wa propaled a a scrount of waik uponsised by the United Siater Gavemment Nerther the Dasted Stater now the Uniled Stales Depasimenl of Energy, nol sny of theis employees. nat ony of their any waranty, expies of implued, employees, makes any waranty, exprest or amplied, or ayumes iny ked

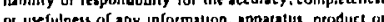

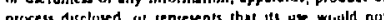

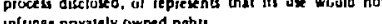

\section{ABS'CRACT}

The purpose of this investigation was to determine the corrosion behavior of a high strength steel (ASTM A416-74 grade 270), typical of those used as tensfoning tendons in prestressed concrete pressure vessels, in several corrosive environments and to demonstrate the protection afforded by coating the steel with either of two commercial petroleum-base greases or portland cement grout. In addition, the few reported incidents of prestressing steel failures in concrete pressure vessels used for containment of nuclear reactors are reviewed. The susceptibility of the steel to stress corrosion cracking and hydrogen embrittlement and its general corrosion rate were determined in several salt solutions. Wires coated with the greases and grout were soaked for long periods in the same solutions and changes in their mechanical properties were subsequently determined. All three coatings appeared to give essentially complete protection but small flaws in the grease saitings were detrimental; flaws or cracks less than $1 \mathrm{~mm}$ wide in the grout were without effect.
\end{abstract}

Key Words: Prestressing steel, high-strength steel, grout, petroleum-base greases, stress-corrosion cracking, hydrogen embrittlement, corrosion, protective coatings.

* Research sponsored jointly by the U.S. Nuclear Regulatory Commission under Interagency Agreements DOE 40-551-75 and 40-552-75 and the Nuclear Power Development Division of the U.S. Department of Energy under Contract W-7405-eng-26 with the Union Carbide Corporation. 


\section{INTRODUCTION}

- Prescressed concrete pressure vessels (PCPVs) for nuclear reactor contalnment are massive structures. They are constructed of relatively highstrength concrete which is heavily reinforced by both conventional steel and a steel posttensioning system consisting of vertical tendons and circumferential wire-strand windings. Performance requirements for PCPVs dictate that extremely large capacity prestressing tendons fabricated from high-strength steels be utilized to reduce the concentration of steel as much as possible. The wires or strands used to make up the prestressing systems are often small in diameter ( 6 to $7 \mathrm{~mm}$ ) and are used at stresses up to $75 \%$ of their ultimate tensile strength (UTS). These two facts make corrosion protection of the tendons imperative if the PCPVs are to operate safely throughout their 30 to 40 year design 1 ife.

Present practice for protecting the tendons in PCPVs is to fill the conduits which contain the tensioned tendons with either a portland cement grout or an organic substance composed of petroleum-based greases or waxes which contain specific additives. Although steels are normally quite compatible with these materials, water leakage into the ducts, particularly if Impurities are present, could cause serious corrosion leading to failure of the load-carrying tendons. It was the inleakage of water into the ducts combined with other unusual circumstances that produced stress corrosion cracking failures of prestressing tendons in a sma11-scale model of a concrete pressure vessel at Oak Ridge National Laboratory. ${ }^{1}$ 
The present investigation was undertaken to determine the corrosion behavior of a typical prestressing steel in several environments and to demonstrate the protection afforded by two different organic materials and by a portland cement grout. Generally, the corrosive environments tested were more severe than those expected to occur in any PCPV. In addition to the experimental program, the few reported incidents of prestressing steel failures in PCPVs for containment of nuclear reactors are briefly reviewed.

EXPERIENCE WITH PRESTRESSING STEELS IN NUCLEAR POWER STATIONS

Prestressed concrete was first used for nuclear pressure vessels in $1960 .^{2}$ As of 1976, fifteen nuclear reactor concrete pressure vessels were scheduled for operation in Europe and the United States with additional PCPVs in various stages of design and construction. ${ }^{3}$ Except for the Fort St. Vrain high-temperature gas-cooled reactor where a PCPV provides primary containment, concrete vessels are used only for secondary containment in water-cooled reactors in the United States. In both cases large number of tendons are used; e.g., in the Fort St. Vrain PCPV 448 tendons each with 169 wires $6.4 \mathrm{~mm}$ in diameter are used, ${ }^{4}$ and in 800 to $1100 \mathrm{MW}(\mathrm{e})$ water-cooled reactors up to $1.1 \times 10^{6} \mathrm{~kg}$ of prestressing steel are employed. 5 Despite the large number of tendons in use, incidents involving corrosion failures are extremely limited.

In 1962 and 1963 during periodic inspections of the tension in the longitudinal and transverse cables in the containment vessels of the Marcoule G.2 and G3 reactors in France, it was noted that the initial tension in some 
of the cables had decreased by $30 \% .^{6}$ Upon unloading and examining one of these cables it was found that approximately $50 \%$ of the wires had broken in bittile fracture with corrosion the apparent cause. Some parts of the circumferential cable which was coated wth several layers of a bltuminous material exhibited minor rust. Prior to examination, protection was provided by periodic sweeps of dried air to maintain the relative humidity of the air adjacent to the cables at 30 to $40 \%$. Failure of the tendons was apparently due to hydrogen embrittlement caused by the excess humidity in the conduits. To prevent further corrosion, the relative humidity of the air was decreased to $10 \%$ and the air flow was changed from periodic to continuous. Since then two additional cables have been replaced, but corrosion has apparently been arrested.

A statutory inspection of prestressing tendons at Wylfa Power Station In the United Kingdor in 1971 revealed extensive pitting of exposed hoop tendons with sowe pits a.s deep as $0.3 \mathrm{~mm} .{ }^{7}$ Corrosion protection of the tendons was by a grease containing a proprietary corrosion inhibitor. Laboratory studies to identify the cause of the pitting concluded that pitting was due to the combined action of contaminating salt from the sea and moisture fron the air. The corrosion inhibitor prevented corrosion only up to a threshold concentration of chloride at which point the inhibitor was unable to prevent attack at susceptible local areas. The corrosion rate was also dependent on the relative humidity with corrosion occurring only at relative humidicies above $33 \%$.

Despite the application of phosphate paints and heavy greases, a number of tendons installed in the bottom cap of the prestressed pressure vessel under construction at Dungeness "B" Power Station in Kent, United Kingdom, 
corroded badly after a short perlod of unstressed storage in conduits. ${ }^{\circ}$ It was later found that water had entered the tendon ducts and emulsifled the grease protecting the tendon wires. Ten tendons containing 1630 wires, each $7 \mathrm{~mm}$ in diameter, were removed and examined, and 1550 wires were found to be severly pitted. An investigation indicated that: the cause of the pitting was electrolytic atcack due to an impressed anodic current from dc welding equipment that had been grounded to metal components of the vessel. Since then dc welding has been prohibited in the vicinity of prestressing materials and subsequent examinations at Dungeness have revealed no further abnormal corrosion.

The condition and functional integrity of nongrouted tendons in secondary contajnment structures in the United States are assessed periodically. PIve vessels prestressed with tendons containing 90 wires of $6.35 \mathrm{~mm}$ diam have been examined. ${ }^{\circ}$ of 7600 wires inspecied, 7 discontinuities were found with all breaks being discovered prior to the completion of construction. A total of 86 wires were removed and only three of these showed evidence of metal 1088 (pitting) amounting to a cross-sectional area reduction of $1 \%$. This attack occurred before application of the final corrosion protection. Metallurgical examination revealed no evidence of stress corrosion cracking or hydrogen embrittlement.

Corrosion observed in the prestressing steel tendons of PCPVs which provide containment for nuclear reactors has not resulted in serious failures to this time. In retrospect, most of the corrosion damage found could have been prevented if proper storage, handing, and construction practices had been followed and well established corrosion prevention practices had been employed. 
EXPERIMENTAL PROCEDLRES

This study involved two separate phases. In one the corrosion of an uncoated typical tendon steel was investigated in several environments, and in the second the behavior of the steel coated with either organic or cement grout coatings was examined in the same corrosive environments. The high strength AISI 1080 carbon steel used in this study was from different heats which conformed to ASTM spectication A416-74, grade 270. The composition of the steel is shown in Table 1. Its minimum UTS is $1860 \mathrm{MPa}(270,000 \mathrm{psi})$. The individual tendon wires were austenitized at approximately $815^{\circ} \mathrm{C}\left(1500^{\circ} \mathrm{F}\right)$, cooled in lead to about $500^{\circ} \mathrm{C}\left(930^{\circ} \mathrm{F}\right)$, and transformed at this temperature to lower pearlite. This pearlite structure was subsequent1y cold worked to provide the high strength.

Corrosion Tssting with Uncoated Wires

A major concern from the corrosion standpoint was stress corrosion cracking. With the uncoated steel, stress corrosion cracking tests were conducteơ using the constant-strain-rate method developed by Humphries and Parkins. ${ }^{9}$ With this technique, a tensile-type specimen while exposed to the test environment is strained at a very slow constant rate until fracture occurs, usually within a period of a few days. By comparing reduction in area, elongation, and/or time to failure under different conditions, the relative susceptibility of a material to cracking in different environments . can be established. Examination of the fracture surface and metallographic examination of the gage section near the fracture can provide additional information about the fracture process. 
Table 1. Composition range of ASTM A416 grade 270 steel used in tests.

- Rlepent

Wt percent ${ }^{a}$

Carbon

$0.75-0.81$

StIIcon

$0.26-0.28$

Lagnese

$0.62-0.84$

Phosphorus

$0.012-0.021$

Sulfux

$0.018-0.028$

Copper

$0.01-0.02$

Iron

Balance

\footnotetext{
heat.

Gaterial supplied from more than one
} 
Fur the stress-corrosion cracking tests the center straight $5 \mathrm{~mm}$ (0.20 in.) diameter wire of a seven-wire tendon was used. light surface rust was removed with fine emory paper and the specimens were degreased in acetone before use. A gage section was not machined in the wires since we wanted to retain the original surface condition of the cold-drawn wire. The wire in the presence of the test environment was strained at a rate of $4.2 \times 10^{-7} / \mathrm{s}$ in an Instron tensile machine. The length between the grips was $0.20 \mathrm{~m}$ ( $8 \mathrm{in.)}$ but only the center $75 \mathrm{~mm}$ ( 3 in.) length was exposed to the solution which was held in a polyvinyl chloride bottle. To prevent any unusual effects at the solution-air tnterface or in the crevice where the wire passed through a rubber stopper in the bottom of the bottle, all the wire except a 75-mm ( 3 1n.) test length at the cer $\therefore$ was coated with a stop-off varnish. After fracture, one end of the specimen was mounted axially and metallographically polished to look for secondary cracks.

The corrosion rates of unstressed wires were determined in several different aqueous environments. In one series of tests, weighed 25-mm (1-in.) lengths of wire were totally immersed in different solutions. In these tests the 5-m-diam wires were placed in 6-mm-diam glass test tubes and were immersed to a depth of about $10 \mathrm{~mm}$ above the specimen height in the test solutions, which included dilute solutions of chloride, nitrate, and sulfate salts, and potable and distilled water. The total volume of solution was only about $500 \mathrm{~mm}^{3}$. These conditions were intended to simulate those that could exist in the interstices of wires in the tendons. Evaporative losses were replaced periodically with distilled water. Although the tubes were open to the air, the small clearance between the tube wall and the specimen restricted access of oxygen to the specimen. As corrosion proceeded, the buildup of corrosion products on the specimen further iinited 
access of oxygen. These tests lasted for $2000 \mathrm{~h}$, but duplicate specimens were removed from test after $1000 \mathrm{~h}$. All specimens were descaled in

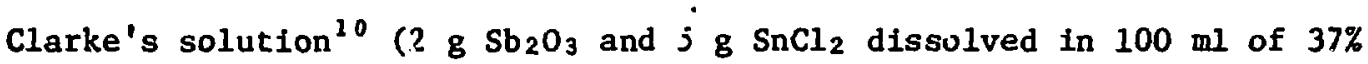
HC1) before final weighing.

In another series of tests, single wires $0.3 \mathrm{~m}$ (12 in.) long were immersed in dilute solutions of $\mathrm{Na}_{2} \mathrm{SO}_{4}$ and $\mathrm{NaCl}$ and in distilled water at room temperature for $6500 \mathrm{~h}$. The volume of sclution was about 1 liter and was freely exposed to air; water lost by evaporation was replaced every few days. The test spicimens extended above the water level so that attack at the water-air interface could be axamined. At the end of the test the specimens were descaled, and the diameter of the wire above and below the waterline was compared.

\section{Testing with Coated Wires}

To evaluate the effectiveness of coating materials in preventing corrosion of tendon steeis, two different types of tests were conducted. In one case, the specimens after coating were stressed to $60 \%$ of the UTS while in contact with the corrosive solution, and in the second the coated specimens were first exposed to the solution for relatively long times without an epplied stress and were subsequently strained to failure. In both cases the center straight wire from the tendon was used, and it had a diameter of $4.36 \mathrm{~mm}(0.17 \mathrm{in.})$ which was slightly less than that of the wires used in the previously described corrosion tests. The two organic coatings used in these tests, desighated "A" and "B", are commercially available petroleuin-based greases containing corrosion inhibitors and 
polar agents to facilitate wetting of the wires and displacement of moisture. They were applied according to the manufacturers' recommendations to a thlckness of about $1 \mathrm{~mm}$. Test specimens protected by grout were prepared by casting $15.9 \mathrm{~mm}(0.6 \mathrm{in.})$ diameter cylinders $3.8 \mathrm{~mm}$ ( $1.5 \mathrm{jin.}$ ) long around the wires. The area of the wires not coated with a grout or grease that could be contacted with the test solutions was covered with a polyurethane Insulating paint. All tests were conducted at ambient temperature except for those using ammonium nitrate solutions, and a conventional tensile machine was used to stress the specimens. In some cases the effect of flaws in the coatings was evaluated. Flaws were placed in the organic coatings by ecraping the wire to which the coating had been applied with a similar wire 8o that a thin strip of unprotected wire resulted. Flaws were cast in grout ranging in width from 0.01 to $3.2 \mathrm{~mm}$ by using plastic shim stock which was removed after the grout hardened.

With the specimens stressed during exposure, only $0.1 M \mathrm{H}_{2} \mathrm{~S}(\mathrm{pH} \sim 4)$ was used as test solution. The organic coatings werc applied to completely cover the wire surface over the $50.8 \mathrm{~mm}(2-i \mathrm{n}$.$) test length and the specimen$ was mounted in a plastic bottle as described above. The grout coated specimens were similarly mounted. The bottle was then filled with demineralized water and $\mathrm{H}_{2} \mathrm{~S}$ was bubbled through the water for about 15 min. The bottle was sealed and the specimen was loaded to $60 \%$ of its UTS and maintained at that level for 6 days unless the specimen failed before then. The length between the grips was $216 \mathrm{~mm}(8.5 \mathrm{in.})$. If failure did not occur within 6 days, the specimen was removed from the environment and pulled to failure at a cross head velocity of $0.51 \mathrm{~mm} / \mathrm{min}$ to determine if the exposure reduced the UTS and ductility (time to failure) compared to controj specimens exposed only to air. 
Coated specimens in the unstressed condition were exposed to solutions of $0.2 \mathrm{M} \mathrm{H} \mathrm{H}_{2} \mathrm{~S}, 0.1 \mathrm{M} \mathrm{NaCl}$, and $0.2 \mathrm{M} \mathrm{NH}_{4} \mathrm{NO}_{3}$. The first two were used at room temperature, but because of the stress corrosion cracking results (see later section), the ammonium nitrate solution was malntained at $66^{\circ} \mathrm{C}\left(150^{\circ} \mathrm{F}\right)$. A $63.5 \mathrm{~mm}$ (2.5-in.) diameter polyvinyl chloride pipe with stoppers in each end was used to expose the gage length of specimens to the $\mathrm{H}_{2} \mathrm{~S}$ solution. Holes were drilled through the pipe and the specimens were centered in these by appropriate sized rubber stoppers (Fig. 1). Water in the pipe was resaturated with $\mathrm{H}_{2} \mathrm{~S}$ at frequent intervais. inxposure to the other two solutions was carried out in stalnless steel pans with holes drilled through the bottom, and the specimens were held in position by means of rubber stoppers. After various exposure times, specimens were removed from the test environment and pulled to fallure at a cross head speed of 0.51 $\operatorname{mom} /$ mi.n.

RESULTS

\section{Stress Corrosion Cracking Tests}

The results from the slow constant strain rate tests are shown in Table 2. Test 1 confirmed that the UTS conformed to ASTM A416 grade 270. Tests 2 through 6 were conducted with $0.2 \mathrm{M} \mathrm{NH}_{4} \mathrm{NO}_{3}$ since shis reagent was suspected of causing failure in the thermal cylinder test at Oak Ridge National Laboratory. ${ }^{1}$ No evidence of cracks was found at 21 and $38^{\circ} \mathrm{C}$, but cracks formed at 52 and $66^{\circ} \mathrm{C}$. Figure 2 shows representative views along the axis of the specimuns tested at the four temperatures. Even though cracks 


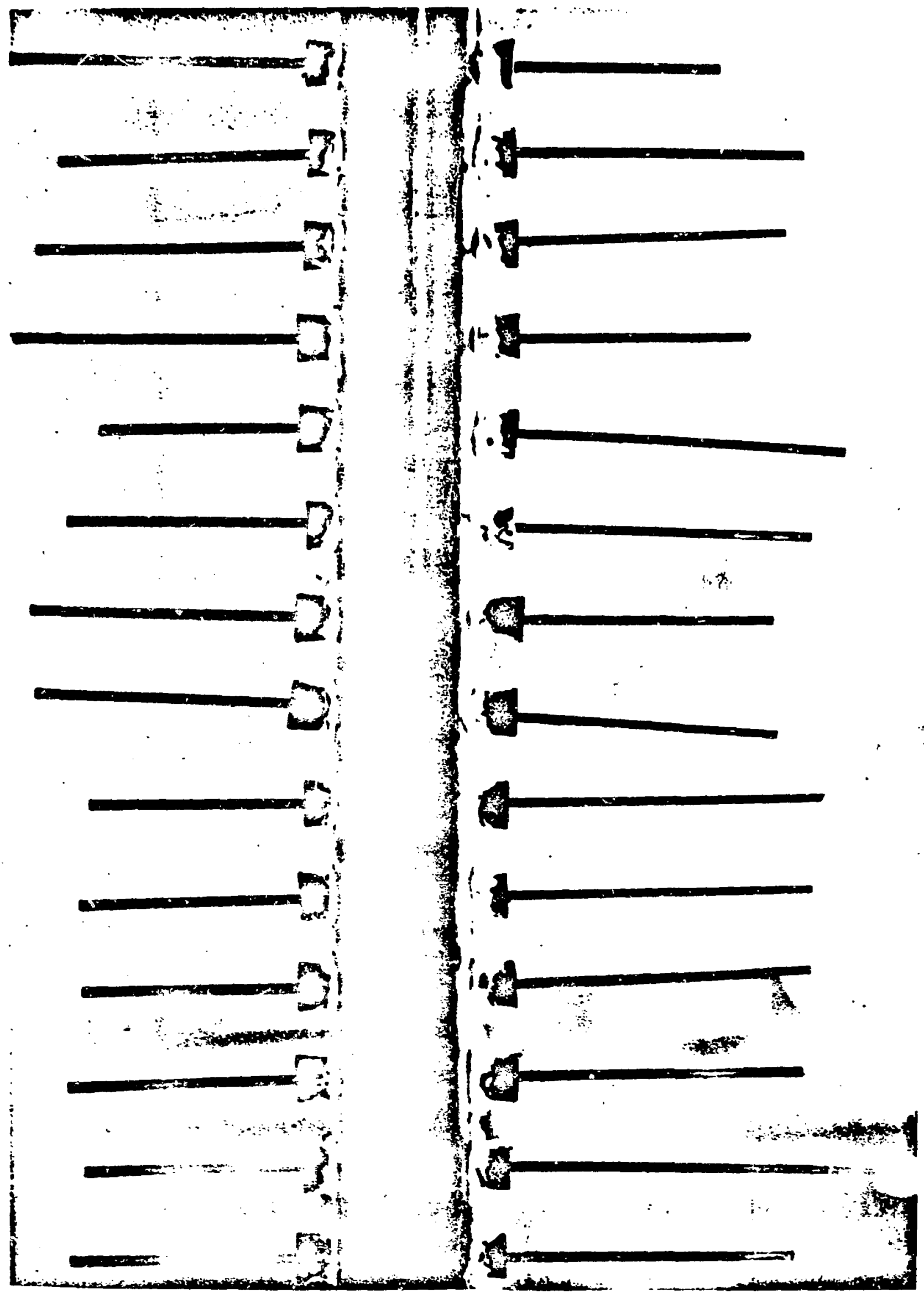

Fig. 1. Photograph of Test Specimens Mounted ir Polyvinyl Chloride Pipe. 
Tab1: 2. Results obtained from constant-strain-rate tests with high-strength steel wires (Strain rate $4.2 \times 10^{-7} / \mathrm{s}$ )

\begin{tabular}{|c|c|c|c|c|c|c|}
\hline & Test medium & $\begin{array}{l}\text { Temperature } \\
{ }^{\circ} \mathrm{C}\end{array}$ & $\mathrm{pH}$ & $\begin{array}{c}\text { Time to } \\
\text { break } \\
\text { (h) }\end{array}$ & $\begin{array}{l}\text { Load } \\
(\mathrm{kN})\end{array}$ & Cracks \\
\hline 1. & Alr & 21 & & 55.5 & 41.9 & No \\
\hline 2. & $0.2 \mathrm{M} \mathrm{NH}_{4} \mathrm{NO}_{3}$ & 2] & 5.0 & 57.5 & 40.1 & No \\
\hline 3. & $0.2 \mathrm{M} \mathrm{NH}_{4} \mathrm{NO}_{3}$ & 2 & 5.3 & 66.5 & 39.3 & No \\
\hline 4. & $0.2 \mathrm{M} \mathrm{NH}_{4} \mathrm{NO}_{3}$ & 30 & 5.3 & 47.0 & 39.0 & No \\
\hline 5. & $0.2 \mathrm{M} \cdot \mathrm{NH}_{4} \mathrm{NO}_{3}$ & 52 & 5.3 & 49.5 & 38.9 & Yes \\
\hline 6. & $0.2 \mathrm{M} \mathrm{NH}_{4} \mathrm{NO}_{3}$ & 66 & 5.0 & 50.5 & 38.9 & Yes \\
\hline 7. & $0.01 \mathrm{MCl}+\mathrm{CaO}$ & 21 & 11.9 & 55.3 & 39.1 & No \\
\hline 8. & $0.01 M \mathrm{KCl}$ & 66 & 5.3 & 60.8 & 38.9 & No \\
\hline 9. & $0.03 \mathrm{M} \mathrm{KCl}$ & 21 & 5.5 & 58.1 & 39.3 & No \\
\hline 10. & $0.03 \mathrm{M} \mathrm{KCl}+\mathrm{HCl}$ & 21 & 3.0 & 60.8 & 39.3 & No \\
\hline 11. & $0.1 M \mathrm{H}_{2} \mathrm{~S}+\mathrm{HCl}$ & 21 & 3.0 & 6.6 & 15.0 & Yes \\
\hline 12. & $0.1 \mathrm{M} \mathrm{H}_{2} \mathrm{~S}$ & 21 & 4 & 4.7 & 11.1 & Yes \\
\hline 13. & $0.001 M \mathrm{Na}_{2} \mathrm{~S}$ & 21 & 11.1 & 57.8 & 38.4 & No \\
\hline 14. & $0.001 M \mathrm{Na}_{2} \mathrm{~S}+\mathrm{HCl}$ & 21 & 7.4 & 53.8 & 39.1 & No \\
\hline 15. & $0.001 M \mathrm{Na}_{2} \mathrm{~S}+\mathrm{HCl}$ & 21 & 4.3 & 19.3 & 35.2 & Yes \\
\hline 16. & $0.003 \mathrm{M} \mathrm{Na}_{2} \mathrm{~S}+\mathrm{HCl}$ & 21 & 4.3 & 17.0 & 34.2 & Yes \\
\hline 17. & $0.0003 M \mathrm{Na}_{2} \mathrm{~S}+\mathrm{HCl}$ & 21 & 6.3 & 52.0 & 39.3 & No \\
\hline 18. & $0.0003 \mathrm{M} \mathrm{Na}{ }_{2} \mathrm{~S}+\mathrm{HCl}$ & 21 & 4.3 & 54.8 & 39.3 & No \\
\hline 19. & Deionized water & 21 & 6.0 & 57.5 & 39.0 & No \\
\hline 20. & Deionized water $+\mathrm{CO}_{2}$ & 21 & 4 & 55.8 & 39.3 & No \\
\hline 21. & $\underset{\substack{\mathrm{H}_{2} \mathrm{O} \\
\mathrm{H}_{3} \mathrm{AsO}_{3}} \mathrm{CO}_{2}+750 \mathrm{ppm}}{ }$ & 21 & 5.1 & 57.6 & 39.3 & No \\
\hline 22. & Zn plate, $\mathrm{H}_{2} \mathrm{O}$ & 21 & 5.8 & 80.6 & 39.5 & No \\
\hline 23. & Zn plate, $0.2 \mathrm{M} \mathrm{Na}_{2} \mathrm{SO}_{4}$ & 21 & 5.7 & 54.9 & 39.5 & No \\
\hline 24. & Corroded in water, 3 days & 21 & 5.9 & 50.9 & 39.3 & No \\
\hline
\end{tabular}



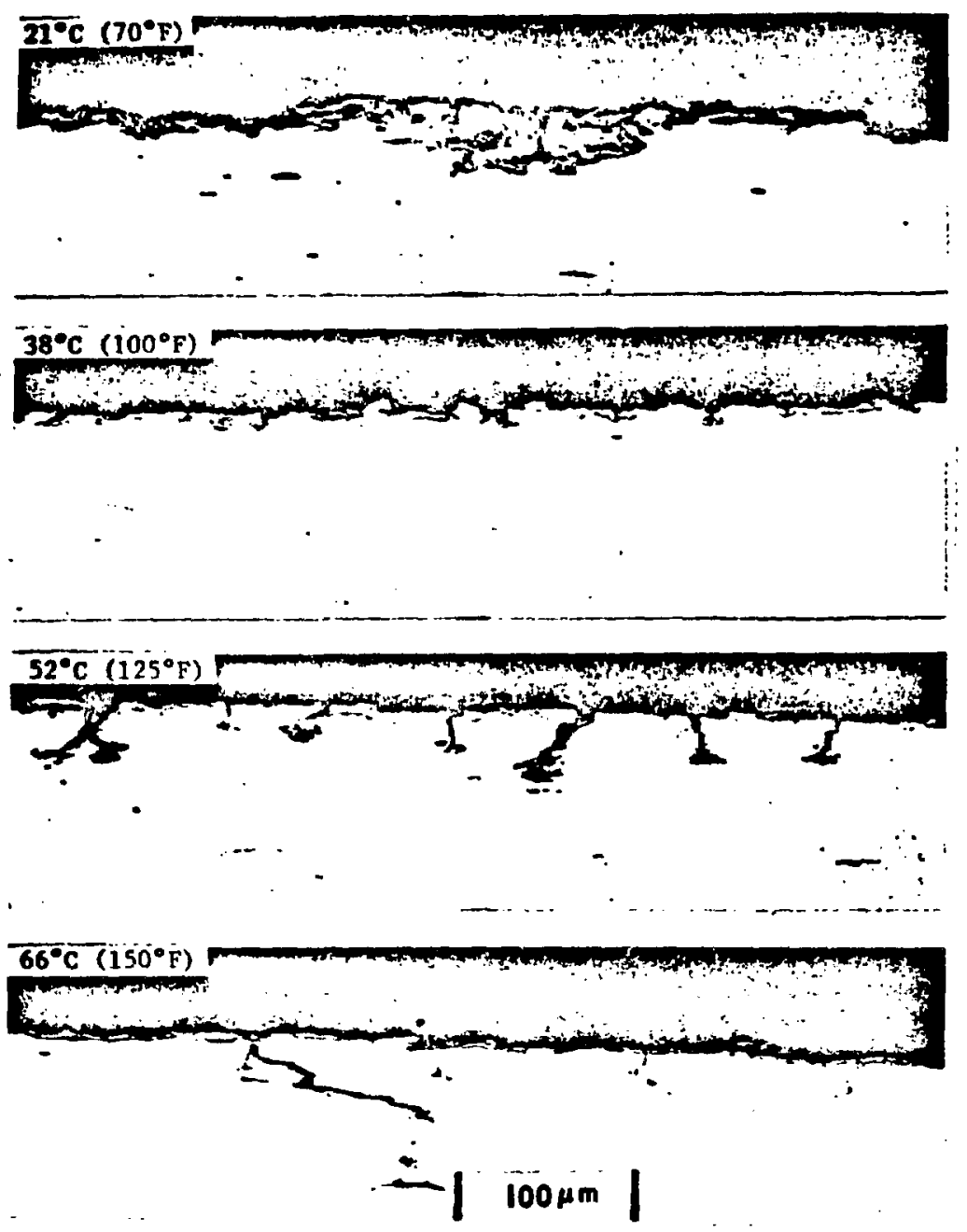

Fig. 2. Attack on Steel Tendons Wires in $0.2 \mathrm{M} \mathrm{NH}_{4} \mathrm{NO}_{3}$. Strain rate, $4.17 \times 10^{-7} / \mathrm{s}$. 
were evident in the steel at the two higher temperatures, no effect on either time to fallure or on the load at fallure was apparent. The large 'dlameter of the wire and the slow rate of crack propagation were responsible for this observation. The formation of cracks at $66^{\circ} \mathrm{C}$ and the absence of cracks at $21^{\circ} \mathrm{C}$ agree with the results from $U$-bend specimens exposed to the same solution; U-bends cracked in a few days at $66^{\circ} \mathrm{C}$ but remained intact at $21^{\circ} \mathrm{C}$ during 100-day tests. ${ }^{1}$

Cracks were not found in any of the specimens exposed to chloridecontaining solutions (tests 7 to 10), regardless of the pH of the solution. These results are in conformance with the generally-accepted belief that chloride ions do not produce cracking in steels of this type.

As expected, $\mathrm{H}_{2} \mathrm{~S}$ produced rapid fallure in the test specimens when the $\mathrm{pH}$ was low and the $\mathrm{H}_{2} \mathrm{~S}$ concentration was relatively high (tests 11 and 12). Figure 3 shows cracks observed in test 12 . In $0.001 \mathrm{M} \mathrm{Na} \mathrm{Na}_{2}$ at a $\mathrm{pH}$ of 11.1 or 7.4 (tests 13 and 14), no cracking was observed, but when the pH was adjusted to 4.3 (test 15), cracking occurred. At this lower concentration, fallure took longer than at the higher sulfide concentration. Cracking occurred slightly faster when the $\mathrm{Na}_{2} \mathrm{~S}$ concentration was increased to $0.003 M$ (test 16 ). When the sulfide concentration was reduced to $0.0003 M$ (test 17 and 18), no cracking was observed even though the $\mathrm{pH}$ of the solutions was less than 7. Although the solutions were sparged with nitrogen before the $\mathrm{Na}_{2} \mathrm{~S}$ was added and the polyvinyl chloride bottle containing the solution was stoppered, it is probable that the small amount of sulfide in the solution was oxidized to sulfur early in the test by traces of oxygen in the bottle. 
16



Fig. 3. Cracks in Tendon Wire Formed During Constant-Strain-Rate Test in $0.1 \mathrm{M} \mathrm{H}_{2} \mathrm{~S}$. 
The rest of Table 2 shows that cracking was not produced in distilled water with carbon dioxide or when arsenious acid was added to the water. In the latter case the wire was heavily plckled in uninhibited hydrochloric acid and remained in the test solution overnight before the specimen was pulled. Electroplating the specimen with zinc, except for an area $200 \mathrm{~mm}^{2}$ in the middle of the wire, also had no effect on cracking in either water or a dilute sodium sulfate solution.

In all cases except where cracking occurred in the presence of sulfide, cup-cone-type fallures were observed, and the reduction in area varied randomily between 36 and $43 \%$ except in test 2 , when it was $47 \%$. In tests 11 and 12, no reduction in area could be measured, and in tests 15 and 16 the reduction in area was on $1 y$. Even though cracks were not observed in most cases, most of the failures occurred in the 75-4m (3-in.) length exposed to the test solution.

Genera1 Corrosion Rate Determinations

The corrosion rates observed for the tendon wires exposed to very small volumes of solutions are shown in Table 3. Each value represents a single specimen. After $1000 \mathrm{~h}$ in some cases and after $2000 \mathrm{~h}$ in most cases, the volume of corrosion products prevented removal of the specimen from the glass tube, and it was necessary to break the tube to recover the specimen. Table 3 shows that under these conditions, corrosion rates were low and nearly Independent of the environment. There was nu significant localized attack in any case. Vacuum fusion analysis of specimens exposed to each solution for $2000 \mathrm{~h}$ showed hydrogen content increases ranging from less than $1 \mathrm{ppm}$ to a maximum of $2.4 \mathrm{ppm}$. 


\begin{tabular}{|c|c|c|}
\hline \multirow{2}{*}{ Test environment } & \multicolumn{2}{|c|}{ Corrosion rate $(\mu \mathrm{m} / \text { year })^{a}$} \\
\hline & $1000 \mathrm{H}$ & $2000 \mathrm{H}$ \\
\hline Potable water & 5.8 & 5.3 \\
\hline Distilled water & 5.1 & 5.3 \\
\hline $0.01 M \mathrm{NaC} 1$ & 6.4 & 9.7 \\
\hline $0.03 M \mathrm{NaCl}$ & 6.6 & 7.9 \\
\hline $0.001 \mathrm{M} \mathrm{NaNO}_{3}$ & 7.4 & 23.1 \\
\hline $0.01 \mathrm{M} \mathrm{NaNO}_{3}$ & $1 i .2$ & 8.1 \\
\hline $0.002 \mathrm{M} \mathrm{Na}_{2} \mathrm{SO}_{4}$ & 5.8 & 7.6 \\
\hline $0.02 \mathrm{M} \mathrm{Na}_{2} \mathrm{SO}_{4}$ & 7.6 & 13.2 \\
\hline $0.2 \mathrm{M} \mathrm{Na}_{2} \mathrm{SO}_{4}$ & 8.9 & 13.5 \\
\hline
\end{tabular}


The $0.3 \mathrm{~m}\left(12-1 \mathrm{n}_{\text {. }}\right)$ long wires exposed to large volumes of solution that was freely exposed to alr corroded more than the specimens with limited air exposure. Corrosion rates calculated from differences in diameter above and below the water line after $6500 \mathrm{~h}$ were 76,152 , and $254 \mu \mathrm{m} / \mathrm{yr}(3,6$, $10 \mathrm{mils} / \mathrm{yr}$ ), respectively, for distilled water, $0.05 \mathrm{M} \mathrm{NaCl}$, and $0.1 \mathrm{M} \mathrm{Na}_{2} \mathrm{SO}_{4}$. Attack was greatest at the solution-air interface, but locailized attack in the form of broad elongated pits was noted below the waterline in all cases. Therefore, maximum penetration rates were considerably greater than indicated above. Comparison of these corrosion rates with those shown in Table 3 clearly shows that free access to oxygen greatly accelerates corroston.

\section{Coated Wires Stressed During Exposure}

A series of tests with bare wires exposed to $0.1 M \mathrm{H}_{2} \mathrm{~S}$ showed that as the stress level Increased both the tIme to failure and the scatter in the data decreased up to about $50 \%$ of the failure stress (Fig. 4). From 50 to $90 \%$, fallures occurred in 1 to 2 hours, independent of stress level.

Results obtained with the coated specimens that were stressed during exposure to $0.1 M{ }^{\mu}$ are summarized in Table 4 . None of the specimens covered with: flawed coatings of either of the organic greases or grout cracked during approximately 6-day exposures at $60 \%$ UTS, and subsequent tensile tests showed that no degradation of either load carrying capacity or ductility (time to fallure) had occurred. Flaws in either organic coatsing resulted in fracture of the wires in short times. On the other hand, 


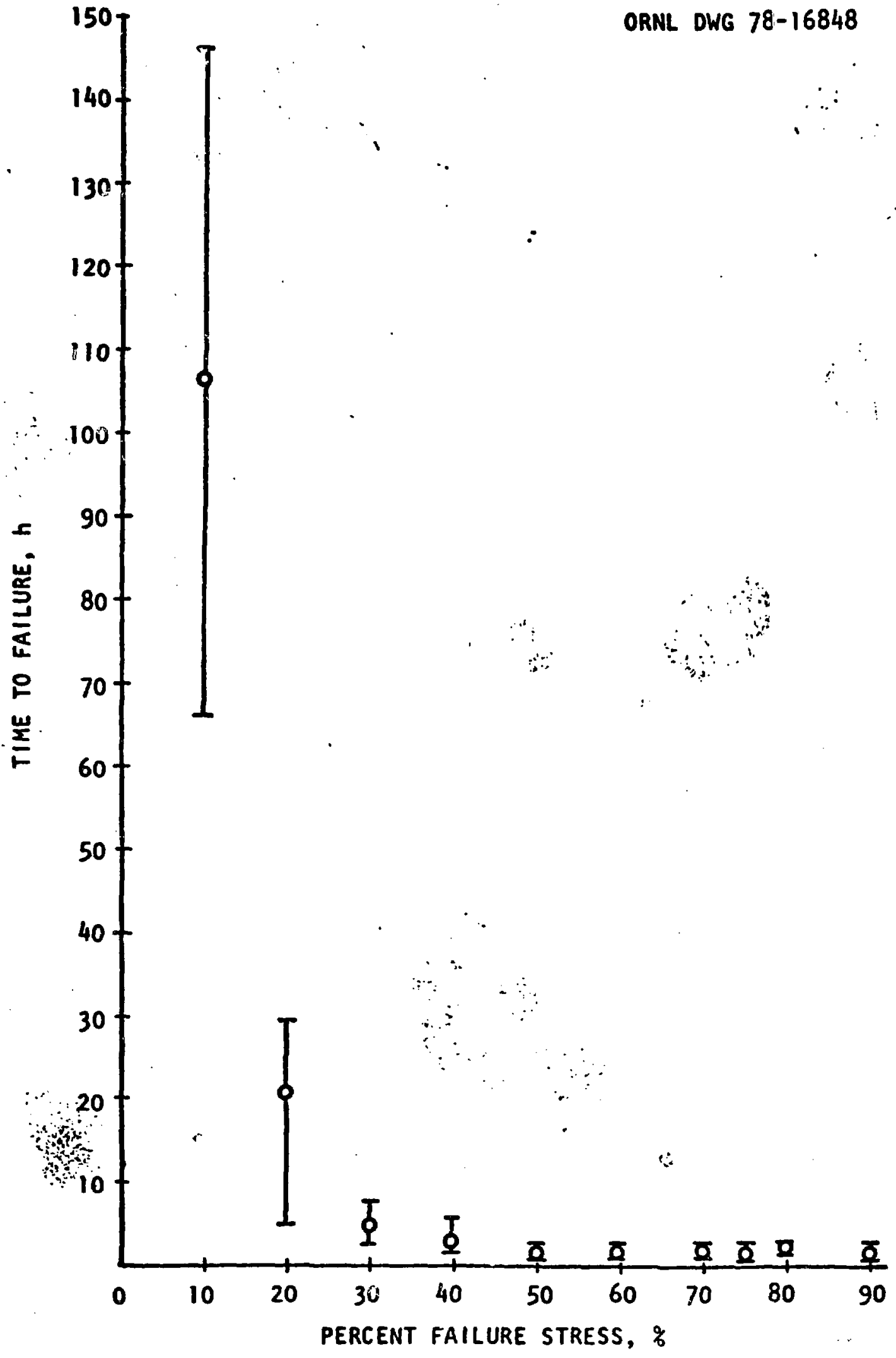

Fig. 4. Effect of Stress (\% UTS) on Time to Failure for Tendon Wire In $0.1 M \mathrm{H}_{2} \mathrm{~S}$. 
Table 4. Loads at fallure and fallure times for specimens exposed in $0.1 M \mathrm{H}_{2} \mathrm{~S}$ at room temperature.

\begin{tabular}{|c|c|c|}
\hline Coating material & $\begin{array}{l}\text { Average fallure } \\
\text { load } a \\
\text { (kN) }\end{array}$ & $\begin{array}{c}\text { Average failure } \\
\text { time } b \\
\text { (h) }\end{array}$ \\
\hline \multicolumn{3}{|l|}{ Orgarifc "A" } \\
\hline Unflawed & 28.58 & 152.0 \\
\hline F1awed & 17.17 & 14.0 \\
\hline \multicolumn{3}{|l|}{ Organic "B" } \\
\hline Unflawed & 28.63 & 149.0 \\
\hline Flawed & 17.17 & 63.8 \\
\hline \multicolumn{3}{|l|}{ Portland cement grout } \\
\hline Unflawed & 28.36 & 162.7 \\
\hline $0.1-\operatorname{mm}$ flaw & 28.60 & 260.0 \\
\hline $0.3-\mathrm{mm}$ flaw & 27.86 & 180.9 \\
\hline 1. 3-mm flaw & 17.17 & 118.3 \\
\hline $1.6-\mathrm{mm}$ flaw & 17.17 & 48.1 \\
\hline 3. 2-min flaw & 17.17 & 34.6 \\
\hline
\end{tabular}

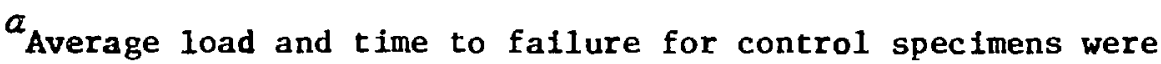
$28.62 \mathrm{kN}$ and $34.7 \mathrm{~min}$, respectively.

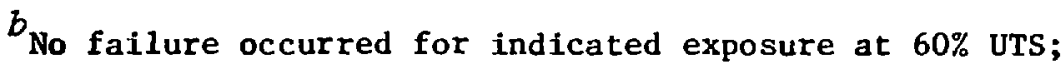
failure load obtained from standard tensile test. 
flaw widths of 0.1 and $0.3 \mathrm{~mm}$ in the grout produced no detrimental effects, but as the flaw width increased beyond $0.3 \mathrm{~mm}$ cracking failures at $60 \%$ UTS occurred in progressively shorter times.

Coated Wires Unstressed During Exposure:

Tables 5, 6, and 7, summarize the results obtained with both coated and uncoated wires that were exposed for various times to $0.1 M \mathrm{H}_{2} \mathrm{~S}, \mathrm{O} .2 \mathrm{M} \mathrm{NH}_{4} \mathrm{NO}_{3}$, and $0.1 M \mathrm{NaCl}$, respectively, without applied strass and then subsequently tenstle tested. The average failure load and time to failure for unexposed spectmens were $28.62 \mathrm{kN}$ and $34.6 .5 \mathrm{mIn}$, respectively.

Table 5 shows that for wires completely covered with either organic materlal or cement grout exposure to $\mathrm{H}_{2} \mathrm{~S}$-saturated water for up to 120 days had little or no effect on UTS or ductility. Completely unprotected specimens under the same condition showed a minor decrease in UTS and a major loss of ductility. Syecimens with flaws in the organic coatings showed significant losses in both ductility and UTS after 119 days and proportionately smaller losses at shorter times (not shown in Table 5). On the'other tand, flaws up to $0.76 \mathrm{~mm}$ wide in portland ceinent grout produced only very minor effects even after 119 days.

In the ammonium nitrate solutions (Table 6) the unprotected wires lost about $14 \%$ in UTS and $66 \%$ in ductility after 42 days and no further changes were noted for the remainder of the 132-day test. Both organic materials provided complete protection for the duration of the test, but the protectivess of the grout seemed to decrease slowly with time. The ammonium 
Table 5. The average load at failure and time to fallure for wires exposed to $0.1 M \mathrm{H}_{2} \mathrm{~S}$ without applied stress and suksequently pulled to failure.

\begin{tabular}{|c|c|c|c|}
\hline Coating material & $\begin{array}{c}\text { Exposure } \\
\text { time } \\
\text { (dars) }\end{array}$ & $\begin{array}{l}\text { Average load } \\
\text { at failure } \\
\text { (kN) }\end{array}$ & $\begin{array}{c}\text { Average time } \\
\text { to failure } \\
\text { (min) }\end{array}$ \\
\hline Ione & 33 & 26.28 & 13.2 \\
\hline Organic "A" & 33 & 27.84 & 34.2 \\
\hline Organic "B" & 33 & 27.98 & 32.6 \\
\hline Portland cement grout & 33 & 27.95 & 32.5 \\
\hline Done & 77 & 26.37 & 13.8 \\
\hline Organfc "A" & 77 & 27.65 & 31.9 \\
\hline Organic "B" & 51 & 28.06 & 35.9 \\
\hline Portland cement grout & 77 & 28.02 & 32.9 \\
\hline None & 120 & 25.36 & 10.4 \\
\hline Organic "A" & 120 & & \\
\hline Organic "B" & 120 & 28.65 & 29.8 \\
\hline Portland cement grout & 120 & 28.43 & 30.6 \\
\hline Plawed organic "A" & 119 & 23.91 & 10.5 \\
\hline Flawed organic "B" & 119 & 24.24 & 12.5 \\
\hline \multicolumn{4}{|l|}{ Portland cement grout } \\
\hline $0.01-\mathrm{mm}$ flaw & 119 & 26.71 & 33.3 \\
\hline $0.10-m$ f1aw & 119 & 26.82 & 34.8 \\
\hline $0.51-\operatorname{mm}$ flaw & 119 & 26.13 & 32.8 \\
\hline 0.76 - $\mathrm{mm}$ flaw & 119 & 25.58 & 32.0 \\
\hline
\end{tabular}

average load and time to failure for control specimens were $28.62 \mathrm{kN}$ and 34.7 min., respectively. 
Table 6. The average load at fallure and time to failure for wires exposed to $0.2 \mathrm{M} \mathrm{NH}{ }_{4} \mathrm{NO}_{3}$ at $66^{\circ} \mathrm{C}$ without applied stress and subsequently pulled to failure.

\begin{tabular}{|c|c|c|c|}
\hline Coating material & $\begin{array}{c}\text { Exposure } \\
\text { time } \\
\text { (days) }\end{array}$ & $\begin{array}{c}\text { Average load } \\
\text { at failure } \\
(\mathrm{kN})\end{array}$ & $\begin{array}{l}\text { Average time } \\
\text { to failure } \\
\text { (min) }\end{array}$ \\
\hline None & 42 & 24.58 & 11.5 \\
\hline Organic "A" & 42 & 27.32 & 36.2 \\
\hline Organic "B" & 42 & 27.24 & 35.1 \\
\hline Portland cement grout & 38 & 28.62 & $34 . ?$ \\
\hline None & 78 & 26.77 & 14.7 \\
\hline Organic "A" & 78 & 28.36 & 34.1 \\
\hline Organic "B" & 78 & 38.39 & 37.1 \\
\hline Portland cement grout & 87 & 38.14 & 27.2 \\
\hline None & 132 & 25.91 & 11.7 \\
\hline Organic "A" & 132 & 28.65 & 35.6 \\
\hline Organic "B" & 132 & 28.47 & 34.3 \\
\hline Portland cement grout & 122 & 26.47 & 25.2 \\
\hline Flawed organic "A" & 130 & 26.47 & 36.0 \\
\hline Flawed "B" & 130 & 26.80 & 33.3 \\
\hline \multicolumn{4}{|l|}{ Portland cement grout } \\
\hline $0.03-\mathrm{mm}$ flaw & 130 & 26.36 & 25.0 \\
\hline $0.25-\mathrm{mm}$ flaw & 130 & 25.80 & 23.0 \\
\hline $0.76-\mathrm{mm}$ flaw & 130 & 25.69 & 22.3 \\
\hline 3.18-mm flaw & 130 & 25.91 & 19.3 \\
\hline
\end{tabular}

$a_{\text {Average load and time to failure for control specimens were } 28.62 \mathrm{kN}}$ and 34.7 min., respectively. 
Table 7. The average load at fallure and time to failure for wires exposed to $0.1 \mathrm{M} \mathrm{NaCl}$ without applied stress and subsequently pulled to failure.

\begin{tabular}{|c|c|c|c|}
\hline Coating material & $\begin{array}{c}\text { Exposure } \\
\text { time } \\
\text { (days) }\end{array}$ & $\begin{array}{l}\text { Average load } \\
\text { at faslure }{ }^{a} \\
(\mathrm{kN})\end{array}$ & $\begin{array}{l}\text { Average time } \\
\text { to failurea } \\
\text { (min) }\end{array}$ \\
\hline None & 71 & 27.53 & 17.8 \\
\hline Organic "A" & 71 & 28.62 & 36.1 \\
\hline Organic "B" & 71 & 28.47 & 36.4 \\
\hline Portland cement grout & 71 & 28.51 & 37.8 \\
\hline None & 107 & 25.72 & 13.9 \\
\hline Organtc "A" & 107 & 27.13 & 30.4 \\
\hline Organic "B" & 107 & 26.99 & 29.5 \\
\hline Portland cement grout & - 107 & 27.02 & 32.9 \\
\hline None & 164 & 24.76 & 12.6 \\
\hline Organic "A" & 164 & 26.34 & 33.0 \\
\hline Organic "B" & 164 & 26.43 & 32.8 \\
\hline Portland cement grout & 164 & 26.80 & 32.4 \\
\hline Flawed organic " $A$ " & 153 & 25.58 & 34.8 \\
\hline $\begin{array}{l}\text { Flawed organic "B" } \\
\text { Portland cement grout }\end{array}$ & 153 & 25.13 & 30.3 \\
\hline $0.03-\operatorname{mm}$ flaw & 153 & 26.58 & 31.5 \\
\hline $0.25-m$ flaw & 153 & 26.91 & 36.5 \\
\hline $0.76-m$ flaw & 153 & 26.24 & 37.3 \\
\hline 3.18-mm flaw & 153 & 23.58 & 8.8 \\
\hline
\end{tabular}

$a_{\text {Average load and time to failure for control specimens were } 28.62 \mathrm{kN}}$ and 34.7 min., respectively. 
nitrate sclution at $66^{\circ} \mathrm{C}$ causes degradation of grout, a fact which probably allowed anmonium nitrate to come in direct contact with the steel after some time. Specimens with flaws in the grout showed about the.same result. On the other hand, specimens with flaws in the organic coatings showed little if any loss in properties, possibly because at $66^{\circ} \mathrm{C}$ the organic greases flowed over the defected areas early in the test and protected them. In the $0.1 M \mathrm{NaCl}$ solution (Table 7) wires protected by all three materials seemed to slowly decrease in UTS and time to failure so that after 164 days the loss was 5 to $7 \%$ in both cases. Unprotected specimens behaved in a similar fashion but the percentage loss in UTS and time to failure were 13 and $64 \%$, respectively, after 164 days. Specimens in which the organic coatings contained flaws showed about the same behavior as the unflawed materfals. Flaws from 0.03 to $0.76 \mathrm{~mm}$ wide in grout coatings had :10 significant effect, but for a flaw $3.18 \mathrm{~mm}$ wide the mechanical properties of the steel were slightly poorer after 153 days than totally unprotected specimens exposed for 164 days.

\section{DISCUSSION}

The steel wires used in this study were made from AISI 1080 steel which was tempered and cold drawn to obtain the high strength required of tendon steels. At room temperature this steel was not susceptible to conventional stress corrosion cracking in the prasence of impurities usually found in grouts or organic coatings (sulfates, nitrates, chlorides) but under some conditions this steel was subject to iydrogen embrittlement. Cracks were produced in ammonium nitrate solution but temperatures had to 
be above room temperature. Aqueous environments produced within grouts or organic greases or waxes containing alkaline-producing additives have high pH values, and its doubtful that cracking would occur in alkaline ammonium nitrate solutions even at higher temperatures. It should be noted, however, that the addition of substantial amounts of calilum chloride (2-5\%) to concrete produces severe pitting in steel embedded in concrete. ${ }^{11,22}$

Test wires failed in short times when strained in solutions of $\mathrm{H}_{2} \mathrm{~S}$ in water at a $\mathrm{pH}$ of 4 or less, but where the $\mathrm{pH}$ was raised to 7 or above cracking failures did not occur. There are, however, reported incidents of cracking occurring at pH values as high as 9.5.13.14 Cracking of highstrength steels in the presence of $\mathrm{H}_{2} \mathrm{~S}$ is due to hydrogen embrittlement, the $\mathrm{H}_{2} \mathrm{~S}$ facilitating the entry of hydrogen into the steel by interferring with the formation of molecular hydrogen in the cathodic part of the corrosiun reaction. 15 Only molecular hydrogen sulfide is effective, 13,14 and is tne $\mathrm{pH}$ of a solution is increased $\mathrm{H}_{2} \mathrm{~S}$ dissociates into $\mathrm{HS}^{-}$and $\mathrm{S}^{-}$ions and cracking does not occur. At the pH of correctly formulated concrete (>12) $\mathrm{H}_{2} \mathrm{~S}$ in the cement is without effect on the mechanical properties of the steel. A similar situation should exist with those greases that contain alkaline-producing additives.

The corrosiveness of several dilute solv:ions to bare high-strength steel wires depended on the availability of oxygen. With restricted access to oxygen corrosion rates were significantly lower than when the solutions. were freely exposed to air. Although we did not investigate the effect of $\mathrm{pH}$ on the corrosion rate of these steels, it is likely that even in the presence of oxygen the corrosion rates would be very low in alkaline solutions. 
Therefore, if pockets of water in contact with tendons should develop in grout- or grease-filled conduits, corrosion of the sicel would be low because of limited availability of oxygen and because of the alkalinity of the solution in contact with grouts or organic materials containing alkaline additives. In such cases hydrogen embrittlement produced by the corrosion reaction is unlikely since even in neutral solutions very little hydrogen was picked up by the steel in 2000-h tests.

All coatings applied to the test specimens provided almost complete protection even though they were tested in environments much more aggressive than would be expected in a PCPV. Those specimens coated with either of the two organic materials selected for study, showed no signs of attack on exposure to $0.1 \mathrm{M} \mathrm{H}_{2} \mathrm{~S}$ when stressed at $60 \%$ UTS for about 6 days. Subsequent tensile tests showed no degradation of mechanical properties. However, if a small amount of coating was removed, failures occurred in relatively short times. Portland cement in the same type of test also provided complete protection, and with flaws up to $0.3 \mathrm{~mm}$ wide no fallures occurred; however with flaw widths of $1.3 \mathrm{~mm}$ or greater, fallures took place in less than 6 days. It seems probably that with a sufficiently small flaw or crack in the relatively thick concrete coating, the pH of the small volume of solution within the crack remained high enough so that the $\mathrm{H}_{2} \mathrm{~S}$ dissociated and cracks could not form.

Exposure of unstressed coated specimens to $0.1 \mathrm{M} \mathrm{H}_{2} \mathrm{~S}$ and subsequent tensile testing also showed the coatings to be completely effective. However, exposure of uncoated specimens and organic coatings with flaws

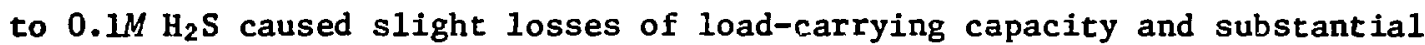


reductions in times to failure during tensile tests. On the other hand, concrete coatings with flaws as wide as 0.76 mm resulted in only very small losses in mechanical properties after exposure to $H_{2} S$. Similar results were obtained in ammonium nitrate and sodium chloride solutions. In the ammonium nitrate solution flaws in either organic coating did not cause loss of mechanical properties, apparently because at the test temperature of $66^{\circ} \mathrm{C}$ the organic materials flowed over the flaws and protected them.

\section{SUMMARY}

The stress-corrosion cracking susceptibility of a typical cold-drawn high-strength steel (ASTM A416 steel 270) to several solutions was determined using a slow constant strain rate technique. The steel developed cracks in $0.2 \mathrm{M} \mathrm{NH}_{4} \mathrm{NO}_{3}$ but only at temperatures above $38^{\circ} \mathrm{C}\left(100^{\circ} \mathrm{F}\right)$. Brittle failures, apparently because of hydrogen embrittlement, also occurred in hydrogen sulfide solutions if the $\mathrm{pH}$ was less than 7. Cracking did not occur in chloride solutions regardless of $\mathrm{pH}$. The corrosion rate of the steel was low in dilute solutions of $\mathrm{NaCl}, \mathrm{NaNO}_{3}, \mathrm{Na}_{2} \mathrm{SO}_{4}$ when access to oxygen was restricted, but it was substantially higher with free access to air; in the latter case broad pits formed, even in pure water.

Both organic coating materials tested and portland cement grout provided complete protection to the steel in the above aggressive environment, provided the coating remained intact. With portland cement crack widths up to $0.76 \mathrm{~mm}$ did not result in loss of protection. These results indicate that in a PCPV the use of certain commercial organic greases or portland cement grout for filling the conduits containing high-strength steel tendons should provide protection to the tendons even if low concentrations of aggressive salts inadvertantly get into the conduits during filling. 


\section{REFERENCES}

1. Canonico, D.A., Griess, J.C., and Robinson, G.S., "Final Report on PCRV Thermal Cylinder Axial Tendon Failures," ORNL-5110, Jan. 1976.

2. Germain, F., Jourmal of the Prestressed Concrete Institute, Vol. 12, No. 4, Aug. 1967, pp. 43-52.

3. Hannah, I.W., "Prestressed Concrete Pressure Vessels in the United Kingdom," Paper 121/75, Experience in the Design, Construction, and Operation of Prestressed Concrete Pressure Vessels and Containments for Nuclear Reactors, University of York, England, Sept. 8-12, 1975.

4. Hildebrand, J.F., "Evaluation of Corrosion Inhibiting Compounds for Protection of Prestressing Systems," Paper 150/75, ibid.

5. Schupack, M, Journal of the Prestressed Concrete Institute, Vol. 17, No. 3, May/June, 1972, pp. 14- 29.

6. Poitevin, P., Containers of the G2 and G3 Reactors: Protection of Prestressing Cables, Technical Information Note Campagnie Industrielle de Travaux (Engerprises Schneider), ORNL translation STS 5651, March 21, 1966.

7. Fontain, M.J. et a1., "Corrosion Protection of Prestressing Tendons," Paper 149/75, Experience in Design, Construction, and Operation of Prestressed Concrete Pressure Vessels and Containments for Nuclear Reactors, University of York, Sept. 8-12, 1975.

8. Rotz, J.V., "Inservice Survetllance of Unbonded Post-Tensioning Systems in Prestressed Concrete Containment Structures," Paper 172/75. ibid. 
9. Humphries, M.J. and Parkins, R.N., In Fundamental Aspects of Stress Comosion Cracking, R. W. Staehle, Ed., National Association of Corrosion Engineers, Houston, 1969, pp. 384-392.

10. Clarke, S.C., Transactions of the Electrochemical Society, Vo. 69,1936, pp. $131-144$.

11. Monfore, G.E. and Verbeck, G.J., Americun Concrete Institute Journal, Vol. 57, No. 11, 1960, pp. 491-515.

12. Treadaway, K.W.T., British Corrosion Joumal, Vol. 6, 1971, pp. $66-72$.

13. Hudgins, C.M. et al, Corrosion, Vol. 22, 1966, pp. 238-251.

14. McCord, T.G. et al, Materials Performance, Vol. 15, No. 2, 1976, pp. $25-34$.

15. Greer, J.B., Materials Performance, Vo1. 14, No. 3, 1975, Pp. 11-22. 